\title{
Analisis Kesalahan Siswa dalam Menyelesaikan Soal Cerita Koordinat Cartesius Menurut Teori Kastolan
}

\author{
1'Ihda Mutimmatul Fitriyah, ${ }^{2}$ Lilin Endah Pristiwati, ${ }^{3}$ Rofi Qoh Sa'adah, \\ ${ }^{4}$ Nikmarocha, ${ }^{5}$ Aning Wida Yanti \\ ${ }_{1}^{1}$ Pendidikan Matematika, Fakultas Tarbiyah dan Keguruan, \\ Universitas Islam Negeri Sunan Ampel Surabaya \\ Jl. Ahmad Yani No.117 Surabaya, 60237 \\ Email: ihdamutimmatulfitriyah@gmail.com
}

Article History:

Received: 10-12-2019; Received in Revised: 04-04-2020; Accepted: 19-08-2020

\begin{abstract}
Kastolan's theory divides 3 types of errors, namely conceptual, computational, and procedural errors. This study aims to analyze students' errors in solving Cartesian coordinate problems according to Kastolan's theory based on mathematical abilities. The subjects were 9 students of class $8 E$ in a school in Surabaya. The method is descriptive qualitative with a test instrument and interviews. The results showed that conceptual errors were the most common mistakes with 12 answers or 54.5\%. The remaining 6 answers or 27.3\% procedural errors and 4 answers or $18.2 \%$ calculation errors. The conceptual errors of subjects with high, medium, and low mathematical abilities are wrong in determining formulas, theorems, or definitions to answer a problem, errors in using formulas and theorems, or inappropriate definitions. In the calculation error, the subject made an error in calculating the value of arithmetic operation and the placement of the constants-variables. Whereas for procedural errors the subject did not work on the problem in systematic steps.
\end{abstract}

Keywords: Errors Analysis; Mathematical Abilities; Kastolan's Theory.

\begin{abstract}
Abstrak
Teori Kastolan membagi 3 jenis kesalahan yaitu kesalahan konseptual, hitung dan prosedural. Penelitian ini bertujuan menganalisis kesalahan siswa dalam menyelesaikan soal cerita koordinat Cartesius menurut teori Kastolan berdasarkan kemampuan matematika. Subjek penelitian ini adalah 9 orang siswa kelas $8 E$ pada salah satu Sekolah di Surabaya. Metode yang digunakan adalah kualitatif deskriptif dengan instrumen tes dan wawancara. Hasil penelitian menunjukkan bahwa kesalahan konseptual merupakan kesalahan yang paling banyak dilakukan yaitu sebanyak 12 jawaban atau 54,5\%. Sisanya 6 jawaban atau 27,3\% kesalahan prosedur dan 4 jawaban atau 18,2\% kesalahan hitung. Pada kesalahan konseptual subjek dengan berkemampuan matematika tinggi, sedang dan rendah, salah dalam menentukan rumus, teorema atau definisi. Untuk menjawab suatu masalah, kesalahan penggunaan rumus dan teorema atau definisi yang tidak sesuai. Pada kesalahan hitung subjek melakukan kesalahan dalam menghitung nilai suatu operasi hitung dan penempatan konstanta-variabel. Sedangkan untuk kesalahan prosedural subjek tidak mengerjakan soal dengan langkahlangkah yang sistematis.
\end{abstract}

Kata Kunci: Analisis Kesalahan; Kemampuan Matematika; Teori Kastolan. 


\section{Pendahuluan}

Matematika adalah salah satu mata pelajaran yang penting untuk diajarkan di sekolah atau madrasah. Hal ini dikarenakan matematika dapat mengembangkan kemampuan berpikir siswa, sehingga siswa dapat menganalisis suatu masalah dengan kritis ${ }^{1}$. Carraher mengungkapkan bahwa mathematics has contributed in important ways to long-standing debates about mathematical concepts, symbolic representation, and the role of contexts in thinking ${ }^{2}$. Matematika berkenaan dengan konsep, representasi simbol, dan aturan dalam konteks berpikir manusia ${ }^{3}$. Hal lain diungkapkan oleh Soedjadi bahwa karakteristik matematika yaitu objeknya abstrak, bertumpu pada kesepakatan, berpola pikir deduktif, memiliki simbol yang kosong dari arti, memperhatikan semesta pembicaraan, dan konsisten dalam sistemnya 4 .

Objek abstrak matematika terdiri dari fakta, konsep, operasi, dan prinsip ${ }^{5}$. Objek abstrak matematika tersebut dapat diamati ketika seseorang sedang atau telah memecahkan soal-soal matematika. Dalam proses pengerjaan atau pemecahan masalah matematika tersebut diamati saat seseorang sedang atau telah mengalami kesalahan atau terdapat kekurangan dalam proses pemecahan masalah tersebut ${ }^{6}$.

Kastolan mengungkapkan 3 jenis kesalahan yaitu kesalahan konseptual, kesalahan strategi dan kesalahan teknik ${ }^{7}$. Kesalahan konseptual adalah kesalahan dalam penggunaan rumus atau definisi dalam menjawab soal, menggunakan rumus atau definisi yang tidak sesuai dengan kondisi atau prasyarat berlakunya rumus. Kesalahan strategi mencakup langkah-langkah pengerjaan yang tidak sistematis dalam pengerjaan soal, tidak dapat atau

${ }^{1}$ Rini Yulia and Awaluddin Awaluddin, "Analisis Kesalahan Siswa Mengerjakan Soal Matematika Di Kelas V SDN 37 Banda Aceh," Jurnal IImiah Mahasiswa Pendidikan Guru Sekolah Dasar 2, no. 1 (2017): 126.

2 David W. Carraher, "Beyond 'Blaming the Victim'and 'Standing in Awe of Noble Savages': A Response to 'Revisiting Lave's "Cognition in Practice,"'” Educational Studies in Mathematics 69, no. 1 (2008): 23-32.

${ }^{3}$ Nurul Farida, “Analisis Kesalahan Siswa SMP Kelas VIII Dalam Menyelesaikan Masalah Soal Cerita Matematika," AKSIOMA: Jurnal Program Studi Pendidikan Matematika 4, no. 2 (2015): 42.

${ }^{4}$ R. Soedjadi, Kiat Pendidikan Matematika Di Indonesia: Konstatasi Keadaan Masa Kini Menuju Harapan Masa Depan (Jakarta: Direktorat Jenderal Pendidikan Tinggi, Departemen Pendidikan Nasional, 2000).

5 Mohammad Faizal Amir, "Analisis Kesalahan Mahasiswa PGSD Universitas Muhammadiyah Sidoarjo Dalam Menyelesaikan Soal Pertidaksamaan Linier," Jurnal Edukasi 1, no. 2 (2015): 135.

6 Julia Noviani, “Analisis Kesalahan Tahapan Kastolan Dan Pemecahan Masalah Model Polya Pada Mata Kuliah Matematika Finansial," Al-Qalasadi: Jurnal IImiah Pendidikan Matematika 3, no. 1 (2019): 29.

${ }^{7}$ Kastolan, Identifikasi Jenis-Jenis Kesalahan Menyelesaikan Soal-Soal Matematika Yang Dilakukan Siswa Kelas 2 Program A1 SMA Negeri Se-Kotamadya Malang. (Malang: IKIP Malang, 1992). 
melakukan kesalahan dalam manipulasi langkah-langkah pengerjaan soal. Sedangkan yang terakhir yaitu kesalahan teknik atau hitung yaitu merupakan kesalahan dalam menghitung atau memecahkan soal ${ }^{8}$.

Kesalahan siswa dalam menyelesaikan persoalan matematika akan berkurang apabila dilakukan latihan secara berkala. Salah satu fakta yang ditemukan pada salah satu sekolah di kota Surabaya yaitu hasil belajar peserta didik pada materi koordinat Cartesius banyak yang memperoleh nilai di bawah KKM yang telah ditetapkan madrasah. Siswa mengalami banyak kesalahan saat diminta untuk mengerjakan soal koordinat Cartesius yang diberikan oleh guru. Kesalahan yang dialami siswa terletak pada penggunaan rumus untuk menentukan suatu titik terhadap titik acuan, kesalahan dalam menghitung dan kesalahan pada konsep definisi suatu titik terhadap garis sumbu 9 .

Berdasarkan penelitian sebelumnya yang dilakukan oleh Bela Sofiana Lenterawati dkk menjelaskan bahwa siswa dengan gaya berpikir sekuensial konkret, sekuensial abstrak dan random konkret sama-sama melakukan kesalahan konsep, prosedural dan teknik pada tipe soal pemahaman, penerapan dan analisis ${ }^{10}$. Penyebab kesalahan yang dilakukan adalah tidak paham konsep sistem persamaan linear dua variabel, tidak teliti, tidak terbiasa menulis jawaban secara lengkap, salah memahami soal, menggunakan cara coba-coba dan tidak hafal. Sedangkan siswa dengan gaya berpikir random abstrak hanya melakukan kesalahan prosedural dan teknik pada tipe soal pemahaman, penerapan dan analisis. Penyebab kesalahannya adalah tidak menggunakan metode penyelesaian sistem persamaan linear dua variabel dengan baik, tidak terbiasa menulis kesimpulan, malas, tidak teliti dan menggunakan cara coba-coba. Penelitian yang dilakukan oleh Nurul Fajriyati Afdila dkk menjelaskan bahwa di setiap soal yang diberikan siswa mengalami kesalahan dimana untuk soal nomor 1 siswa melakukan kesalahan konseptual sebanyak (66,7\%), kesalahan prosedural dan teknik (88,9\%). Soal nomor 2 kesalahan prosedural sebanyak $(77,8 \%)$ dan kesalahan teknik $(88,9 \%)$, dan soal nomor 3 kesalahan teknik sebanyak (83,3\%). Faktor penyebab yang kesalahan yang dilakukan siswa diantaranya karena siswa kurang cermat membaca dan memahami soal dengan baik, siswa hanya menghafal rumus

${ }^{8}$ Sitti Sahriah, "Analisis Kesalahan Siswa dalam Menyelesaikan Soal Matematika Materi Operasi Pecahan Bentuk Aljabar Kelas VIII SMP Negeri 2 Malang.," SKRIPSI Jurusan Teknik Mesin - Fakultas Teknik UM 0, no. 0 (December 2, 2013), http://karyailmiah.um.ac.id/index.php/TM/article/view/24348.

${ }^{9}$ Hasil observasi awal pada bulan Agustus 2019

10 Bela Sofiana Lenterawati, Ikrar Pramudya, and Yemi Kuswardi, "Analisis Kesalahan Berdasarkan Tahapan Kastolan Dalam Menyelesaikan Soal Cerita Sistem Persamaan Linear Dua Variabel Ditinjau Dari Gaya Berpikir Siswa Kelas VIII SMP Negeri 19 Surakarta Tahun Pelajaran 2018/2019," Jurnal Pendidikan Matematika Dan Matematika SOLUSI 3, no. 5 (n.d.): 471-482. 
tanpa memahami konsep dan siswa kurang teliti dalam mengerjakan soal ${ }^{11}$. Penelitian lain yang dilakukan Aditya Juliant dkk menjelaskan bahwa dalam menyelesaikan soal siswa melakukan kesalahan dalam mengorganisasikan data sebesar 16,67\%, melakukan kesalahan dalam memanipulasi data sebesar 30,56\%, kesalahan dalam membuat kalimat sebesar 5,56\% dan kesalahan dalam menarik kesimpulan sebesar $2,78 \%{ }^{12}$.

Berdasarkan penelitian tersebut, artikel ini mencoba mendeskripsikan kesalahan siswa menurut teori Kastolan. Namun berbeda dengan penelitian sebelumnya, artikel ini mengungkapkan pengategorian kemampuan matematika siswa dan materi yang digunakan adalah koordinat Cartesius.

\section{Metode}

Jenis penelitian yang digunakan dalam penelitian ini adalah penelitian deskriptif kualitatif yaitu untuk memahami fenomena yang dialami subjek penelitian tanpa melakukan generalisasi terhadap hal-hal yang diperolehnya dari hasil penelitian ${ }^{13}$. Penelitian ini dilaksanakan pada salah satu sekolah di Surabaya pada hari Jumat tanggal 28 September 2019. Subjek penelitian diambil dari kelas VIII-E tahun ajaran 2019/2020 sebanyak 9 siswa dengan kemampuan matematika tinggi, sedang dan rendah. Nilai kemampuan siswa tersebut berdasarkan rekap nilai ulangan dan tugas-tugas matematika kelas VIII mulai dari semester 1 .

Teknik pengumpulan data pada penelitian ini adalah wawancara dan tes tertulis berupa soal cerita koordinat Cartesius. Wawancara dilakukan secara bebas terpimpin yaitu gabungan antara wawancara bebas dan wawancara terpimpin. Wawancara bebas berupa kegiatan tanya jawab bebas antara pewawancara dan responden, namun pewawancara tetap menggunakan tujuan penelitian sebagai pedoman. Sedangkan dalam wawancara terpimpin, pertanyaan yang akan diajukan sesuai dengan daftar pertanyaan yang telah disusun ${ }^{14}$. Soal yang diberikan merupakan soal yang dirancang oleh peneliti dan sudah dilakukan validasi soal oleh ahli yaitu guru matematika di sekolah subjek penelitian. Berikut adalah soal tes yang digunakan untuk menguji kesalahan siswa:

${ }^{11}$ Nurul Fajriyati Afdila, Yenita Roza, and Maimunnah, “Analisis Kesalahan Siswa Dalam Menyelesaikan Masalah Kontekstual Materi Bangun Ruang Sisi Datar Berdasarkan Tahapan Kastolan," LEMMA : Letters of Mathematics Education 5, no. 1 (Desember 2018): 65-72, https://doi.org/10.22202/jl.2018.v5i1.3383.

12 Aditya Juliant and Kurnia Noviartati, “Analisis Kesalahan Siswa Dalam Menyelesaikan Soal Pada Materi Pola Bilangan Ditinjau Dari Kemampuan Matematika Siswa," Jurnal Riset Pendidikan 2, no. 2 (November 2016): 111-18.

13 Lexi J.Moleong, Metodelogi Penelitian Kualitatif (Bandung: PT Remaja Rosdakarya, 2015), 6.

${ }^{14}$ Cholid Narbuko and Abu Achmadi, Metode Penelitian (Jakarta: Bumi Aksara, 1999), 84 
Tabel 1. Soal Tes Tertulis Siswa

No. Soal

1. Dalam suatu denah, kota Surabaya dipetakan dalam sistem koordinat Cartesius. Balai Kota terletak pada koordinat $(0,0)$, Tugu Pahlawan terletak pada koordinat $(-3,2)$, wisata religi Sunan Ampel terletak pada koordinat $(-1,6)$, monumen Kapal Selam terletak pada koordinat $(3,-2)$, monumen Bambu Runcing terletak pada koordinat $(1,-3)$, wisata kebun binatang Surabaya (KBS) terletak pada koordinat $(-1,-4)$, dan masjid Al Akbar terletak pada koordinat $(-6,-5)$.

Berdasarkan informasi tersebut gambarlah titik-titik tersebut ke dalam koordinat Cartesius kemudian tentukan :

a. Jarak Tugu Pahlawan terhadap sumbu- $x$.

b. Posisi wisata religi Sunan Ampel terhadap balai kota.

c. Posisi Masjid Al Akbar terhadap wisata kebun binatang Surabaya (KBS).

2. Dalam suatu bidang koordinat Cartesius, titik $A(-3,3), B(-3,6)$, dan $\mathrm{C}(1,6)$. Tentukan:

a. Koordinat titik D, sehingga jika keempat titik tersebut dihubungkan akan membentuk persegi panjang.

b. Luas persegi panjang ABCD.

Teknik analisis data yang digunakan berdasarkan tahapan Kastolan yang terdiri dari tiga jenis kesalahan yaitu kesalahan konseptual, hitung dan prosedural. Adapun pengelompokan kesalahan Kastolan yaitu: (1) Kesalahan konseptual jika siswa salah menentukan rumus, teorema atau definisi untuk menjawab suatu masalah; penggunaan rumus, teorema atau definisi yang tidak sesuai dengan kondisi prasyarat penggunaan ketiganya; dan tidak menuliskan rumus, teorema atau definisi untuk menjawab suatu masalah, (2) Kesalahan hitung jika siswa salah dalam menghitung nilai dari suatu operasi hitung; dan salah dalam penulisan atau memindahkan konstanta-variabel dari satu langkah ke langkah berikutnya, dan (3) Kesalahan prosedural jika langkah-langkah siswa dalam pengerjaan soal tidak sistematis; tidak dapat atau melakukan kesalahan dalam manipulasi langkah-langkah pengerjaan soal.

\section{Hasil dan Diskusi}

Pelaksanaan penelitian ini dilakukan dengan terlebih dahulu memberikan tes tertulis dengan materi koordinat Cartesius kemudian dilakukan wawancara kepada subjek penelitian. Pelaksanaan wawancara pada penelitian ini bertujuan untuk mengetahui secara lebih mendalam mengenai kesalahan yang dilakukan siswa beserta faktor penyebabnya. Berdasarkan 
hasil analisis data didapatkan jenis - jenis kesalahan yang dialami oleh siswa sebagai berikut:

Tabel 2. Hasil Jawaban Siswa

\begin{tabular}{|c|c|c|c|}
\hline \multirow{2}{*}{$\begin{array}{l}\text { Inisial } \\
\text { Siswa }\end{array}$} & \multirow{2}{*}{$\begin{array}{c}\text { Kemampuan } \\
\text { Siswa }\end{array}$} & \multicolumn{2}{|c|}{ Jenis Kesalahan } \\
\hline & & Soal No.1 & Soal No.2 \\
\hline WZA & Tinggi & $\begin{array}{l}\text { a. - } \\
\text { b. - } \\
\text { c. - }\end{array}$ & $\begin{array}{l}\text { a. } \quad- \\
\text { b. Prosedural }\end{array}$ \\
\hline MFA & Tinggi & $\begin{array}{l}\text { a. - } \\
\text { b. - } \\
\text { c. - }\end{array}$ & $\begin{array}{l}\text { a. } \quad- \\
\text { b. Prosedural }\end{array}$ \\
\hline ZLF & Tinggi & $\begin{array}{l}\text { a. - } \\
\text { b. Konseptual } \\
\text { c. Konseptual }\end{array}$ & $\begin{array}{l}\text { a. } \quad- \\
\text { b. Prosedural }\end{array}$ \\
\hline MLA & Sedang & $\begin{array}{l}\text { a. - } \\
\text { b. - } \\
\text { c. Konseptual }\end{array}$ & $\begin{array}{l}\text { a. } \quad- \\
\text { b. Prosedural }\end{array}$ \\
\hline $\mathrm{AK}$ & Sedang & $\begin{array}{ll}\text { a. } & - \\
\text { b. Konseptual } \\
\text { c. Konseptual }\end{array}$ & $\begin{array}{l}\text { a. - } \\
\text { b. Prosedural }\end{array}$ \\
\hline NT & Sedang & $\begin{array}{l}\text { a. - } \\
\text { b. Konseptual } \\
\text { c. Hitung }\end{array}$ & $\begin{array}{l}\text { a. - } \\
\text { b. Hitung }\end{array}$ \\
\hline FFA & Rendah & $\begin{array}{ll}\text { a. } & \text { Konseptual } \\
\text { b. } & - \\
\text { c. } & \text { Konseptual } \\
\end{array}$ & $\begin{array}{l}\text { a. }- \\
\text { b. Prosedural }\end{array}$ \\
\hline MFK & Rendah & $\begin{array}{ll}\text { a. } & - \\
\text { b. Konseptual } \\
\text { c. Konseptual }\end{array}$ & $\begin{array}{ll}\text { a. } & - \\
\text { b. } & \text { Hitung }\end{array}$ \\
\hline MIRS & Rendah & $\begin{array}{ll}\text { a. } & - \\
\text { b. Konseptual } \\
\text { c. Konseptual }\end{array}$ & $\begin{array}{ll}\text { a. } & - \\
\text { b. Hitung }\end{array}$ \\
\hline
\end{tabular}

\section{Analisis dan Pembahasan Kesalahan Konseptual}

Kesalahan konseptual merupakan kesalahan dalam menggunakan atau menafsirkan suatu istilah, konsep atau prinsip. Terdapat 3 bentuk kesalahan yang dapat dikategorikan menjadi jenis kesalahan konseptual, yaitu (1) kesalahan menentukan rumus, teorema atau definisi untuk menjawab suatu masalah; (2) kesalahan penggunaan rumus, teorema atau definisi yang tidak sesuai dengan kondisi prasyarat penggunaan ketiganya; dan (3) tidak menuliskan rumus, teorema atau definisi untuk menjawab suatu masalah. 
Kesalahan yang paling banyak dilakukan adalah kesalahan konseptual yaitu sebanyak 12 jawaban atau 54,5\% dari semua kesalahan. Gambar 1 merupakan pembahasan hasil jawaban subjek penelitian yang mengalami kesalahan konseptual.

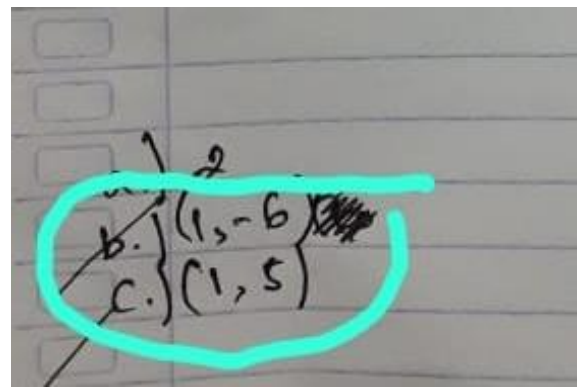

Gambar 1. Hasil jawaban soal no.1b subjek AK

Wawancara tentang kesalahan konseptual pada soal no.1b subjek AK yang memiliki kemampuan matematika sedang

$P \quad:$ Bagaimana kamu bisa memperoleh koordinat $(1,-6) ?$

$S$ : Jadi saya memperoleh koordinat itu dengan menghitung manual bu, pakai langkah satuan. Jadi dari koordinat wisata religi ampel ke balai kota dengan ke kanan 1 langkah kemudian ke bawah 6 langkah bu. Karena ke kanan positif dan ke bawah negatif jadi ketemu koordinatnya $(1,-6)$

$P$ : Kalau diminta cari koordinat wisata religi ampel terhadap balai kota berarti kamu lihatnya dari wisata religi ampel atau balai kota?

$S$ : Wisata religi ampel bu?

$P$ : Yakin?

$S \quad:$ Eh salah bu. Dari balai kota ya?

$P$ : Iya. Terus koordinat balai kota berapa sih?

$S:(0,0)$

Oh iya bu, kalau balai kotanya $(0,0)$ berarti untuk cari koordinat wisata religi ampel cukup lihat koordinat aslinya saja ya bu?

$P$ : Iya bener. Jadinya berapa koordinat wisata religi ampel terhadap balai kota?

$S:(-1,6) b u$

Berdasarkan penggalan pekerjaan dan wawancara subjek AK tersebut, dapat diketahui bahwa sebenarnya AK sudah menguasai konsep cara mengerjakan soal jenis ini, hal ini didukung dengan hasil wawancara AK yang menyadari letak kesalahannya. Faktor penyebab terjadinya kesalahan AK adalah lupa bahwa untuk pertanyaan $1 \mathrm{~b}$ akan lebih mudah dijawab dengan konsep posisi titik terhadap titik asal mengingat balai kota koordinatnya $(0,0)$, sehingga tidak perlu menghitung dengan langkah satuan. 


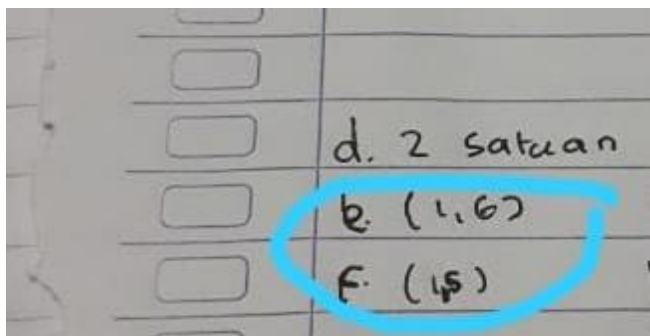

Gambar 2. Hasil jawaban soal no.1c subjek MIRS

Wawancara tentang kesalahan konseptual pada soal no.1c subjek MIRS yang memiliki kemampuan matematika rendah seperti yang terlihat pada Gambar 2 adalah sebagai berikut:

$P \quad:$ Bagaimana kamu bisa memperoleh koordinat $(1,5) ?$

$S$ : Saya memperoleh koordinat itu dengan menghitung pakai langkah satuan bu. Jadi dari koordinat Masjid al Akbar ke KBS dengan ke atas 1 langkah kemudian ke kanan 5 langkah bu. Karena ke atas positif dan ke kanan positif jadi ketemu koordinatnya $(1,5)$

$P$ : Kalau diminta cari koordinat titik $A$ terhadap $B$ kamu jalannya dari titik $A$ apa titik $B$ ?

$S$ : Titik $A$ bu

$P$ : Oke kalau dari titik A ya, sebenarnya yang diminta cari itu koordinat titik $A$ apa titik $B$ ?

$S$ : Titik $A$ bu

$P$ : Yakin?

$S$ : Iya bu yakin aku

$P$ : Oke, saya mau tanya lagi arah atas-bawah itu buat sumbu-X apa $Y$ ? Terus kanan-kiri itu buat sumbu-X apa Y?

$S$ : Eh iya bu, kan atas-bawah itu buat sumbu-Y karena dia sumbu vertikal terus kanan-kiri itu buat sumbu-X horizontal. Berarti jawaban saya salah ya bu?

$P$ : Yang benar koordinatnya berapa?

$S$ : $(5,1)$ tinggal dibalik bu sama yang awal

Berdasarkan penggalan pekerjaan dan wawancara subjek MIRS tersebut, dapat diketahui bahwa sebenarnya AK antara sudah menguasai konsep cara mengerjakan soal jenis ini dan tidak, hal ini didukung dengan hasil wawancara AK yang menyadari 1 letak kesalahannya tapi 1 yang lain tidak. Faktor penyebab terjadinya kesalahan MIRS adalah lupa konsep menentukan nilai $x$ dan nilai $y$ dalam titik koordinat, dimana dalam langkah satuan untuk kanankiri merupakan nilai $x$ dan atas-bawah merupakan nilai $y$. Selanjutnya MIRS tidak menyadari letak kesalahannya terhadap posisi titik terhadap titik acuan, dengan ini bisa dikatakan bahwa MIRS masih belum memahami konsep posisi titik terhadap titik acuan. 


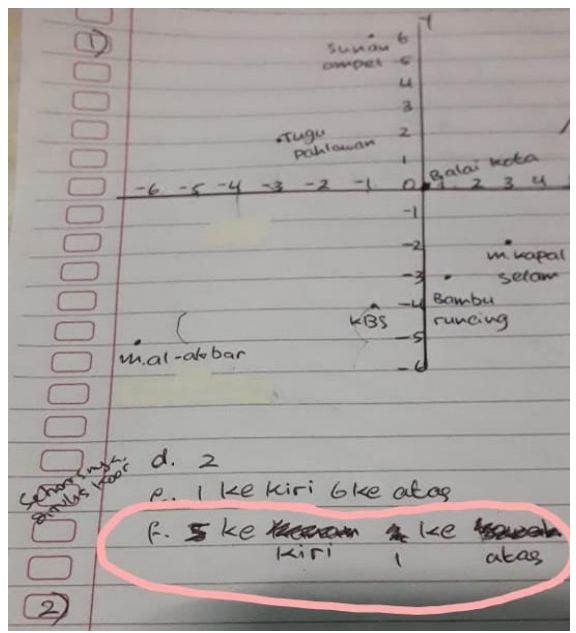

Gambar 3. Hasil jawaban soal no.1c subjek ZLF

Wawancara tentang kesalahan konseptual pada soal no.1c subjek ZLF yang memiliki kemampuan matematika tinggi berdasarkan gambar 3 tersebut adalah:

$P \quad:$ Bagaimana kamu bisa memperoleh jawaban 5 ke kiri 1 ke atas?

$S$ : Saya dapat itu dengan menghitung manual bu, langkah satuan. Jadi dari koordinat KBS ke masjid Al Akbar dengan ke kiri 5 langkah kemudian ke atas 1 langkah bu. Eh bentar bu, saya salah hitung seharusnya ini ke bawah bukan ke atas

$P$ : Jadi yang benar gimana?

$S$ : Ke kiri 5 langkah kemudian ke bawah 1 langkah bu

$P \quad:$ Kemudian koordinatnya jadi berapa?

$S:(-5,-1) b u$

$P$ : Itu kok gak kamu tulis dilembar jawabanmu? Yang ditanya sebenarnya apa sih, langkahnya apa koordinatnya?

$S$ : Koordinat bu hehehe. Berarti salah ya bu? Seharusnya $(-5,-1)$

$P$ : Iya

Berdasarkan penggalan pekerjaan dan wawancara subjek ZLF tersebut, dapat diketahui bahwa sebenarnya ZLF sudah menguasai konsep cara mengerjakan soal jenis ini, hal ini didukung dengan hasil wawancara ZLF yang menyadari letak kesalahannya. Faktor penyebab terjadinya kesalahan ZLF adalah kurang fokus dalam mengerjakan soal, hal ini terbukti dengan dia sadar bahwa seharusnya bukan ke atas 1 langkah tetapi ke bawah 1 langkah. Kemudian ZLF kurang teliti dalam melihat apa yang ditanyakan pada soal. Yang dimaksud soal adalah dimana posisi masjid Al Akbar terhadap KBS, namun ZLF hanya menjawab langkahnya saja, tidak menuliskannya dalam bentuk koordinat. 
2. Analisis dan Pembahasan Kesalahan Hitung

Terdapat 2 bentuk kesalahan yang dapat dikategorikan menjadi jenis kesalahan hitung, yaitu (1) kesalahan dalam menghitung nilai dari suatu operasi hitung; dan (2) kesalahan dalam penulisan atau memindahkan konstanta-variabel dari satu langkah ke langkah berikutnya. Kesalahan hitung yang dilakukan oleh subjek penelitian adalah 18,2\% dari total jawaban yang salah. Berikut merupakan pembahasan hasil jawaban subjek penelitian yang mengalami kesalahan hitung :

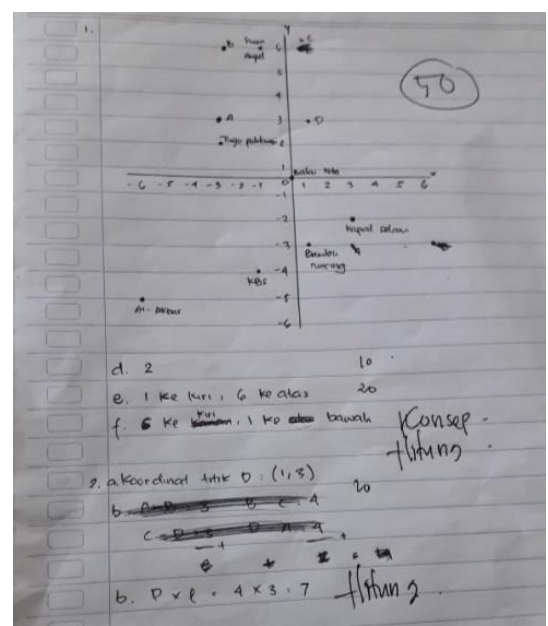

Gambar 4. Hasil jawaban soal no.1c dan 2b subjek NT

Wawancara tentang kesalahan hitung pada soal no.1c subjek NT yang memiliki kemampuan matematika sedang

$P$ : Bagaimana kamu bisa memperoleh jawaban 6 ke kiri dan 1 ke bawah?

$S$ : Saya memperoleh jawaban itu dengan menggunakan langkah satuan bu. Jadi dari KBS ke Masjid Al Albar itu 1,2,3,4,5 (sambil menghitung ulang) ke kiri. Bu saya tadi salah hitung, seharusnya 5 ke kiri bukan 6 ke kiri

$P$ : Oke berarti tau ya salahnya dimana.

$S$ : Iya bu

Wawancara tentang kesalahan hitung pada soal no.2b subjek NT yang memiliki kemampuan matematika sedang seperti terlihat pada Gambar 4 sebagai berikut:

$P \quad$ : Bagaimana kamu bisa memperoleh jawaban 7 ini?

$S$ : Itu bu dari menghitung luas persegi panjang ABCD. Saya hitung dari $B$ ke $C$ itu 4 langkah jadi panjangnya 4 kemudian dari $A$ ke $B$ itu 3 langkah jadi lebarnya 3. Kemudian rumus luas persegi panjang kan panjang $\times$ lebar jadilah $4 \times 3 \mathrm{bu} .7 \mathrm{deh}$ 
$P \quad: 4 \times 3=7 ?$ sudah yakin?

$S$ : Eh salah bu, salah hitung hehehe seharusnya 12 bu. Yang 7 itu $4+3$ Jadi yang bener luasnya 12 bu

Berdasarkan penggalan pekerjaan dan wawancara subjek NT tersebut, dapat diketahui bahwa sebenarnya NT sudah menguasai konsep cara mengerjakan soal jenis ini baik itu nomor 1 dan 2, hal ini didukung dengan hasil wawancara NT yang menyadari letak kesalahannya. Faktor penyebab terjadinya kesalahan NT adalah kurang teliti dalam menghitung banyak langkah satuan ke kiri dari KBS ke masjid Al Akbar serta salah menghitung perkalian antara 4 dengan 3.

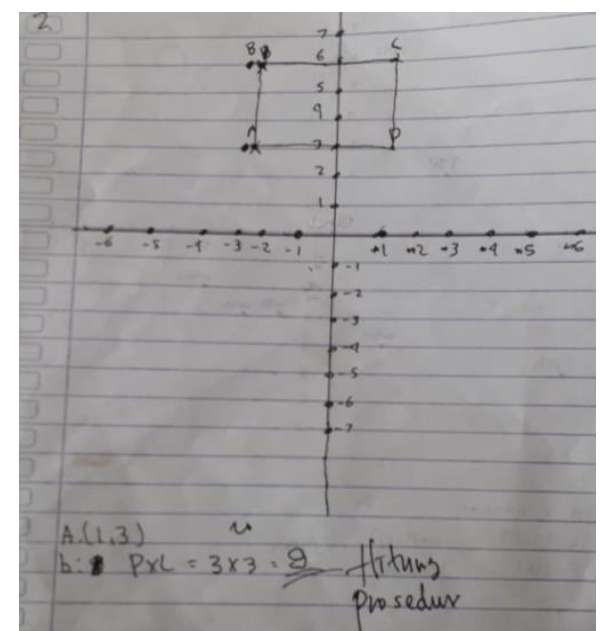

Gambar 5. Hasil jawaban soal no.2b subjek MIRS

Wawancara tentang kesalahan hitung pada soal no.2b subjek MIRS yang memiliki kemampuan matematika sedang berdasarkan gambar 5 sebagai berikut:

$P \quad:$ Bagaimana kamu bisa memperoleh jawaban 9 ini?

$S$ : Itu bu dari menghitung luas persegi panjang ABCD. Saya hitung dari $B$ ke $C$ itu 3 langkah jadi panjangnya 3 kemudian dari A ke B itu 3 langkah jadi lebarnya 3. Kemudian rumus luas persegi panjang kan panjang $\times$ lebar jadilah $3 \times 3 \mathrm{bu} .9$ deh

$P$ : B ke C 3 langkah? sudah yakin?

$S$ : Bentar bu saya hitung ulang dulu

1,2,3,4. 4 langkah Oh iya bu salah hitung wkwk tadi ada yang keloncat jadi ketemunya 3 langkah. Berarti kalau gitu luas yang saya temukan juga salah bu. Yang bener $4 \times 3=12.12$ bu luasnya.

Berdasarkan penggalan pekerjaan dan wawancara subjek MIRS tersebut, dapat diketahui bahwa sebenarnya MIRS sudah paham cara mengerjakan soal jenis ini, hal ini didukung dengan hasil wawancara MIRS yang menyadari letak 
kesalahannya. Faktor penyebab terjadinya kesalahan MIRS adalah kurang teliti dan terlalu terburu-buru dalam menghitung banyak langkah dari B ke C sehingga berakibat fatal dengan hasil luas yang ditemukannya.

3. Analisis dan Pembahasan Kesalahan Prosedural

Terdapat 2 bentuk kesalahan yang dapat dikategorikan menjadi jenis kesalahan prosedural, yaitu (1) jika langkah-langkah siswa dalam pengerjaan soal tidak sistematis; dan (2) tidak dapat atau melakukan kesalahan dalam manipulasi langkah-langkah pengerjaan soal. Kesalahan prosedural yang dilakukan oleh subjek penelitian adalah 27,3\% dari semua kesalahan. Berikut merupakan pembahasan hasil jawaban subjek penelitian yang mengalami kesalahan prosedural :

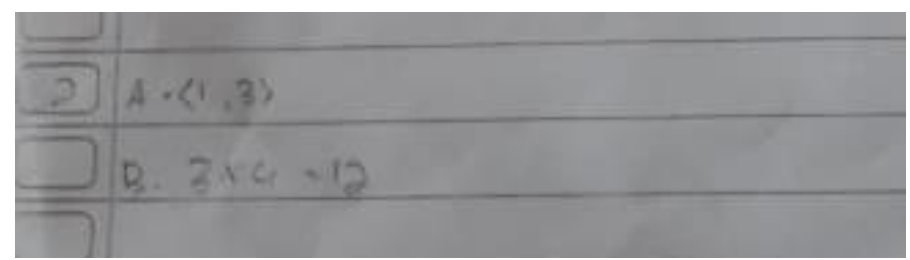

Gambar 6. Hasil jawaban soal no. 2b subjek WZA

Wawancara tentang kesalahan prosedural pada soal no.2b subjek WZA yang memiliki kemampuan matematika tinggi berdasarkan Gambar 6 sebagai berikut:

$P \quad:$ Bagaimana kamu bisa memperoleh jawaban 12 ini?

$S$ : Yang diminta kan luas persegi panjang ABCD. Jadi saya harus cari panjangnya dengan menghitung langkah dari $B$ ke $C$ yaitu 4 langkah jadi panjangnya 4 kemudian dari A ke B itu 3 langkah jadi lebarnya 3. Kemudian rumus luas persegi panjang kan panjang $\times$ lebar jadilah $4 \times 3=12 b u$

$P \quad:$ Oke betul. Terus kenapa kamu kok nulisnya langsung $4 \times 3=12$ ? Semisal saya gak paham maksud tulisanmu itu apa bagaimana?

$S$ : Singkat aja bu langsung $4 \times 3=12$. Hehehe iya bu itu yang susah. Kalau seperti itu saya nulisnya harus nyantumin panjang dan lebarnya bu?

$P \quad:$ Lebih baik gitu, prosedural atau langkah-langkahnya jelas

$S$ : Jadi saya nulisnya harus gini ta bu? $L=P \times L=4 \times 3=12$

$P$ : Iya

Berdasarkan penggalan pekerjaan dan wawancara subjek WZA tersebut, dapat diketahui bahwa sebenarnya WZA sudah paham cara mengerjakan soal jenis ini, hal ini didukung dengan hasil wawancara WZA yang menyadari letak 
kesalahannya. Kesalahan WZA adalah menjawab dengan tidak prosedural. Pada gambar 6, terlihat bahwa subjek WZA langsung menuliskan hasilnya. Tidak hanya subjek WZA, terdapat 2 siswa yang memiliki kemampuan tinggi, juga melakukan kesalahan yang sama. Selain itu, kesalahan yang serupa juga dilakukan oleh siswa yang memiliki kemampuan matematika sedang sebanyak 2 siswa dan yang memiliki kemampuan rendah sebanyak 1 siswa yang melakukan kesalahan secara prosedural.

\section{Kesimpulan}

Kesalahan yang dilakukan subjek penelitian dalam menyelesaikan soal cerita koordinat Cartesius berdasarkan tahapan Kastolan terdiri atas kesalahan konseptual, hitung dan prosedural. Kesalahan yang paling banyak dilakukan adalah kesalahan konseptual yaitu sebanyak 12 jawaban atau 54,5\% dari semua kesalahan. Bentuk kesalahan yang dilakukan adalah kesalahan menentukan dan penggunaan rumus, teorema atau definisi yang berupa kesalahan dalam menulis koordinat, kesalahan menentukan nilai $x$ dan nilai $y$ pada titik koordinat, dan kesalahan penggunaan konsep titik acuan.

Kesalahan hitung yang dilakukan oleh subjek sebanyak 4 jawaban atau $18,2 \%$. Bentuk kesalahan yang dilakukan adalah kesalahan dalam menghitung nilai dari suatu operasi hitung dan kesalahan dalam penulisan atau memindahkan konstanta-variabel dari satu langkah ke langkah berikutnya. Bentuknya, kesalahan dalam menghitung langkah satuan dalam koordinat Cartesius dan menghitung luas suatu bangun yang ditentukan berdasarkan koordinat titik dalam koordinat Cartesius.

Kesalahan prosedural yang dilakukan oleh subjek penelitian sebanyak 6 jawaban atau 27,3\% dari semua kesalahan. Bentuk kesalahan yang dilakukan adalah langkah-langkah subjek penelitian dalam pengerjaan soal tidak sistematis. Siswa berkemampuan matematika tinggi, sedang dan rendah memiliki ranah kesalahan yang hampir sama karena pada intinya mereka kurang teliti dan terburu-buru dalam mengerjakan.

\section{Daftar Pustaka}

Afdila, Nurul Fajriyati, Yenita Roza, and Maimunnah. "Analisis Kesalahan Siswa Dalam Menyelesaikan Masalah Kontekstual Materi Bangun Ruang Sisi Datar Berdasarkan Tahapan Kastolan." LEMMA : Letters of Mathematics Education 5, no. 1 (Desember 2018): 65-72. https://doi.org/10.22202/jl.2018.v5i1.3383.

Amir, Mohammad Faizal. "Analisis Kesalahan Mahasiswa PGSD Universitas Muhammadiyah Sidoarjo Dalam Menyelesaikan Soal Pertidaksamaan Linier." Jurnal Edukasi 1, no. 2 (2015): 2443-0455. 
Carraher, David W. "Beyond 'Blaming the Victim'and 'Standing in Awe of Noble Savages': A Response to 'Revisiting Lave's "Cognition in Practice."'” Educational Studies in Mathematics 69, no. 1 (2008): 23-32.

Farida, Nurul. "Analisis Kesalahan Siswa SMP Kelas VIII Dalam Menyelesaikan Masalah Soal Cerita Matematika." AKSIOMA: Jurnal Program Studi Pendidikan Matematika 4, no. 2 (2015).

J.Moleong, Lexi. Metodelogi Penelitian Kualitatif. Bandung: PT Remaja Rosdakarya, 2015.

Juliant, Aditya, and Kurnia Noviartati. "Analisis Kesalahan Siswa Dalam Menyelesaikan Soal Pada Materi Pola Bilangan Ditinjau Dari Kemampuan Matematika Siswa." Jurnal Riset Pendidikan 2, no. 2 (November 2016): 111-18.

Kastolan. Identifikasi Jenis-Jenis Kesalahan Menyelesaikan Soal-Soal Matematika Yang Dilakukan Siswa Kelas 2 Program A1 SMA Negeri SeKotamadya Malang. Malang: IKIP Malang, 1992.

Lenterawati, Bela Sofiana, Ikrar Pramudya, and Yemi Kuswardi. "Analisis Kesalahan Berdasarkan Tahapan Kastolan Dalam Menyelesaikan Soal Cerita Sistem Persamaan Linear Dua Variabel Ditinjau Dari Gaya Berpikir Siswa Kelas VIII SMP Negeri 19 Surakarta Tahun Pelajaran 2018/2019." Jurnal Pendidikan Matematika Dan Matematika SOLUSI 3, no. 5 (n.d.): 471-482.

Narbuko, Cholid, and Abu Achmadi. Metode Penelitian. Jakarta: Bumi Aksara, 1999.

Noviani, Julia. “Analisis Kesalahan Tahapan Kastolan Dan Pemecahan Masalah Model Polya Pada Mata Kuliah Matematika Finansial." Al-Qalasadi: Jurnal Ilmiah Pendidikan Matematika 3, no. 1 (2019): 27-39.

Sahriah, Sitti. "Analisis Kesalahan Siswa dalam Menyelesaikan Soal Matematika Materi Operasi Pecahan Bentuk Aljabar Kelas VIII SMP Negeri 2 Malang." SKRIPSI Jurusan Teknik Mesin - Fakultas Teknik UM0, no. 0 (December 2, 2013). http://karyailmiah.um.ac.id/index.php/TM/article/view/24348.

Soedjadi, R. Kiat Pendidikan Matematika Di Indonesia: Konstatasi Keadaan Masa Kini Menuju Harapan Masa Depan. Jakarta: Direktorat Jenderal Pendidikan Tinggi, Departemen Pendidikan Nasional, 2000.

Yulia, Rini, and Awaluddin Awaluddin. "Analisis Kesalahan Siswa Mengerjakan Soal Matematika Di Kelas V SDN 37 Banda Aceh.” Jurnal IImiah Mahasiswa Pendidikan Guru Sekolah Dasar 2, no. 1 (2017). 